\title{
Are Normal Kidney Cells Influenced by Aspirin in Cell Culture?
}

\author{
Ahmadi R, Sagharjoghi Farahani M*, Gravand F
}

\begin{abstract}
Aspirin is today widely used to lessen mild pain and fever, reduce inflammation and prevent heart attacks and strokes. The reports indicate that aspirin also has anticancer effects. This study was exerted to determine the effects of aspirin on proliferation of normal kidney (HEK) cells in cell culture. In this laboratory experimental study, HEK cells were exposed to $10 \mathrm{mg} / \mathrm{ml}, 1 \mathrm{mg} / \mathrm{ml}$, $0.1 \mathrm{mg} / \mathrm{ml}, 0.01 \mathrm{mg} / \mathrm{ml}$ and $0.001 \mathrm{mg} / \mathrm{ml}$ of aspirin in cell culture. After 48 hours, the viability of HEK cells was examined using MTT assay. The data was analyzed using ANOVA. Our findings show that viability of HEK cells decreased significantly when exposed to $10 \mathrm{mg} / \mathrm{ml}$ of aspirin. Other doses of aspirin resulted in increased viability. Our findings show that aspirin has anti-proliferative effects against HEK cells only in lower dose.
\end{abstract}

Keywords-Aspirin, Viability, HEK cells.

\section{INTRODUCTION}

A SPIRIN is a common painkiller first introduced by the drug and dye firm Bayer in 1899. [1] It is classified among the nonsteroidal antiinflammatory drugs (NSAIDs) that causes several different effects in the body, mainly the reduction of inflammation, analgesia (relief of pain), the prevention of clotting, and the reduction of fever. [2] It is on the WHO Model List of Essential Medicines, the most important medications needed in a basic health system. Salicylic acid, the active ingredient of aspirin, was first isolated from the bark of the willow tree in 1763 by Edward Stone of Wadham College, University of Oxford. It is one of the most widely used medications in the world. Aspirin is also used long-term, at low doses, to help prevent heart attacks, strokes, and blood clot formation in people at high risk of developing blood clots. Low doses of aspirin may be given immediately after a heart attack to reduce the risk of another heart attack or of the death of cardiac tissue. It may be effective at preventing certain types of cancer, particularly colorectal cancer. The main side effects of aspirin are gastrointestinal ulcers, stomach bleeding, and ringing in the ears, especially with higher doses. While daily aspirin can help prevent a clot-related stroke, it may increase risk of a bleeding stroke. In children and adolescents, aspirin is not recommended for flu-like symptoms or viral illnesses.[1]-[4] Aspirin is used in the treatment of a number of conditions, including fever, pain, rheumatic fever, and inflammatory diseases, such as rheumatoid arthritis, pericarditis, and Kawasaki disease. [5] It is an

Morteza Sagharjoghi Farahani (*corresponding author) is with Department of Molecular and Cellular Sciences, Faculty of Advanced Sciences \& Technology, Pharmaceutical Sciences Branch, Islamic Azad University, Tehran-Iran(IAUPS).

Rahim Ahmadi (PhD) is with the Department of Physiology, Faculty of Basic Sciences, Islamic Azad University, Hamedan Branch, Hamedan, Iran.

Foruzan Gravand (MSc) is with the Department of Physiology, Faculty of Basic Sciences, Islamic Azad University, Hamedan Branch, Hamedan, Iran. effective analgesic for acute pain, but is generally considered inferior to ibuprofen for the alleviation of pain because aspirin is more likely to cause gastrointestinal bleeding. It is an important part of the treatment of those who have had a myocardial infarction. [6]

Human Embryonic Kidney 293 cells, also often referred to as HEK 293, HEK-293, 293 cells, or less precisely as HEK cells, are a specific cell line originally derived from human embryonic kidney cells grown in tissue culture. HEK 293 cells are very easy to grow and transfect very readily and have been widely used in cell biology research for many years. They are also used by the biotechnology industry to produce therapeutic proteins and viruses for gene therapy. HEK 293 cells were generated in 1973 by transformation of cultures of normal human embryonic kidney cells with sheared adenovirus 5 DNA in Alex van der Eb's laboratory in Leiden, The Netherlands. [7]

Recent studies show that aspirin has also anti-cancer effects. This study was exerted to determine the effects of aspirin on proliferation of HEK cells in cell culture.

\section{MATERIAL AND METHODS}

In this laboratory experimental study, Aspirin was prepared as powder and different concentrations of aspirin $(10 \mathrm{mg} / \mathrm{ml}$, $1 \mathrm{mg} / \mathrm{ml}, 0.1 \mathrm{mg} / \mathrm{ml}, 0.01 \mathrm{mg} / \mathrm{ml}, 0.001 \mathrm{mg} / \mathrm{ml}$ ) were used in our study.

We used MTT assay in this work to determine the effects of aspirin on HEK cells viability in cell culture. Briefly, the procedure was continued and carried out in the following steps:

Day One: $100 \mu$ l of cells was added into each well (96 well plate) and incubate at 37 with $5 \%$ co2 overnight.

Day Two: The media was removed and drug suspension was added and incubated at 37 with 5\%co2 overnight. For control $10 \%$ FBS was added to media

Day Three: drug suspension was removed from media, $20 \mu 1$ MTT was added to each well and incubated for 4 hours at $37 \mathrm{oC} .150 \mu$ isopropanol was added and covered with tinfoil and agitate cells on orbital shaker for $15 \mathrm{~min}$. Absorbance was read at $570 \mathrm{~nm}$ with a reference filter of 630 and recorded.

Statistical significance was evaluated by one-way analysis of variance (ANOVA) using SPSS 19. Differences with $\mathrm{P}<0.05$ were considered significant.

\section{RESULTS}

Figure I shows the viability of HEK cells in response to different doses of aspirin. 


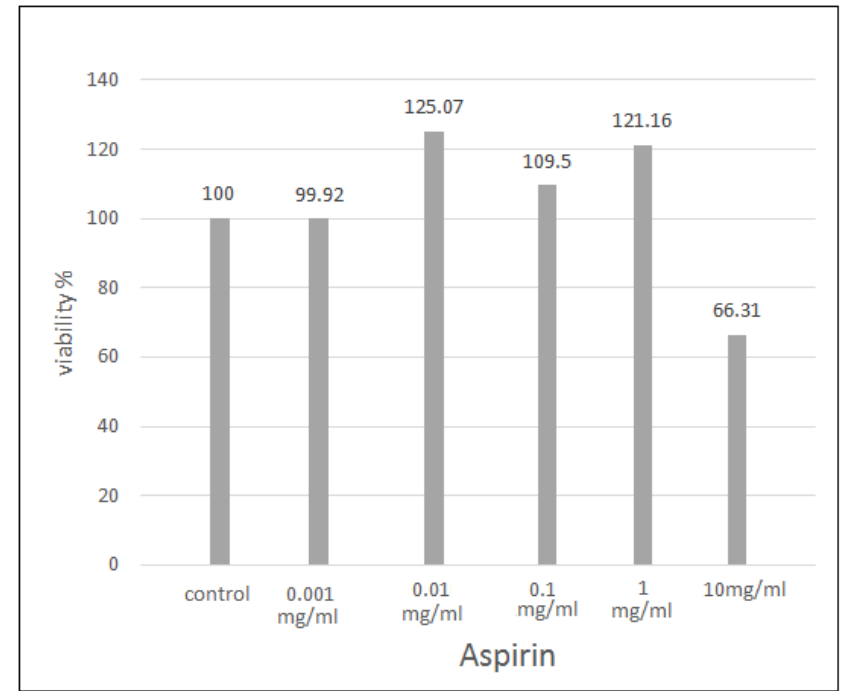

Fig I. Viability of HEK cells in response to different doses of aspirin in cell culture.

Our findings show that viability of HEK cells decreased in response to $10 \mathrm{mg} / \mathrm{ml}$ of aspirin. However, viability of HEK cells increased in response $0.01,0.1,1 \mathrm{mg} / \mathrm{ml}$ of aspirin.

\section{DISCUSSION}

Our results indicated that proliferation of HEK cells are reduced in response to high dose of aspirin, however, low doses of aspirin had no effect on proliferation of HEK cells or might have enhancing effects on proliferation of HEK cells. Studies show that aspirin may influence proliferation of cells including cancer cells.[8],[9] Studies also suggest that exposing cells to low nontoxic aspirin dosages could induce gene expression alterations that may lead to the efflux transporter protein over-expression, thus increasing cellular detoxification of aspirin[10] ; according to which it is expected that low doses of aspirin not to impair normal cells growth and functions. It has also been shown that aspirin is more effective than diclofenac against the growth of rhabdomyosarcoma cell line. [11] Recent studies suggest that aspirin might provide therapeutic benefit in the adjuvant treatment of certain forms of cancer. [23], [24]

\section{CONCLUSION}

We have shown that high dose of aspirin has impairing effects on normal kidney cell proliferation in cell culture.

\section{ACKNOWLEDGMENT}

We appreciate all who helped us to exert the present study.

\section{REFERENCES}

[1] Polo Friz H, Molteni M, Cimminiello C. The dogma of aspirin: a critical review of evidence on the best monotherapy after dual antiplatelet therapy. Thromb J. 2015 Sep 7;13:28. http://dx.doi.org/10.1186/s12959-015-0059-8

[2] Wu ZK, Wang JJ, Wang T, Zhu SS, Chen XL, Liu C, Zhang WG. Clopidogrel resistance response in patients with coronary artery disease and metabolic syndrome: the role of hyperglycemia and obesity. J Geriatr Cardiol. 2015 Jul;12(4):378-82.

[3] Lewis, H. D.; Davis, J. W.; Archibald, D. G.; Steinke, W. E.; Smitherman, T. C.; Doherty Je, J. E et al. Protective Effects of Aspirin against Acute Myocardial Infarction and Death in Men with Unstable Angina. New England Journal of Medicine. 1983; 309 (7): 396-403. http://dx.doi.org/10.1056/NEJM198308183090703
[4] Julian DG, Chamberlain DA, Pocock SJ. A comparison of aspirin and anticoagulation following thrombolysis for myocardial infarction (the AFTER study): a multicentre unblinded randomised clinical trial. BMJ. 1996 Dec 7;313(7070):1429-31. http://dx.doi.org/10.1136/bmj.313.7070.1429

[5] Gersony WM. Diagnosis and management of Kawasaki disease. JAMA. 1991; 265:2699-703. http://dx.doi.org/10.1001/jama.1991.03460200079040

[6] Sachs CJ. Oral analgesics for acute nonspecific pain. Am Fam Physician. 2005 Mar 1;71(5):913-8.

[7] Jaluria P, Chu C, Betenbaugh M, Shiloach J. Cells by design: a mini-review of targeting cell engineering using DNA microarrays. Mol Biotechnol. 2008 Jun;39(2):105-11 http://dx.doi.org/10.1007/s12033-008-9048-5

[8] López-Lázaro M. Understanding why aspirin prevents cancer and why consuming very hot beverages and foods increases esophageal cancer risk. Controlling the division rates of stem cells is an important strategy to prevent cancer. Oncoscience. 2015 Nov 10;2(10):849-56.

[9] Zhang YP, Wan YD, Sun YL, Li J, Zhu RT. Aspirin might reduce the incidence of pancreatic cancer: A meta-analysis of observational studies. Sci Rep. 2015 Oct 21;5:15460. http://dx.doi.org/10.1038/srep15460

[10] Massimi I, Ciuffetta A, Temperilli F, Ferrandino F, Zicari A, Pulcinelli FM, et al. 2015;2015:607957. Multidrug Resistance Protein-4 Influences Aspirin Toxicity in Human Cell Line. Mediators Inflamm.

[11] Al-Nimer MS, Hameed HG, Mahmood MM. Antiproliferative effects of aspirin and diclofenac against the growth of cancer and fibroblast cells: In vitro comparative study. Saudi Pharm J. 2015 Oct;23(5):483-6. http://dx.doi.org/10.1016/j.jsps.2015.01.002

[12] Kraus S, Sion D, Arber N. Can We Select Patients for Colorectal Cancer Prevention with Aspirin? Curr Pharm Des. 2015;21(35):5127-34.

http://dx.doi.org/10.2174/1381612821666150915111000 